\title{
Principal component analysis on the perceptions of milk producers about Rhipicephalus (Boophilus) microplus control in Minas Gerais
}

\author{
Análise de componente Principal da percepção dos produtores de leite sobre \\ o controle do Rhipicephalus (Boophilus) microplus em Minas Gerais \\ Christiane Maria Barcellos Magalhães da Rocha ${ }^{1 *}$; Fábio Raphael Pascoti Bruhn ${ }^{1}$; Romário Cerqueira Leite ${ }^{2}$; \\ Antônio Marcos Guimarães ${ }^{1}$; Ivan Barbosa Sampaio²; Paulo Roberto de Oliveira² \\ ${ }^{1}$ Laboratório de Epidemiologia, Departamento de Medicina Veterinária, Universidade Federal de Lavras - UFLA, Lavras, MG, Brasil \\ ${ }^{2}$ Escola de Veterinária, Universidade Federal de Minas Gerais - UFMG, Belo Horizonte, MG, Brasil
}

Received October 3, 2011

Accepted November 23, 2011

\begin{abstract}
Milk producers in Lavras, Passos and Divinópolis, Minas Gerais, were interviewed with the aim of evaluating their perceptions and attitudes regarding control over Rhipicephalus (Boophilus) microplus. Multivariate correlation between the variables was done by means of principal component analysis. The producers' perceptions and attitudes regarding $R$. (B.) microplus were similar: most of them did not have any basic knowledge of tick biology or control, and they applied acaricide products through backpack spraying, without any defined technical criteria. Some of the results obtained were: I. a negative correlation between schooling level and the frequency of spraying cattle with acaricides; II. a positive correlation between milk production, quality of equipment for acaricide application and technological level of the farm; III. farm properties with greater production and technification tended to keep the intervals between acaricide applications constant over the course of the year. After applying principal component analysis, a positive correlation was observed between schooling level, technological level of the farm and perceptions regarding $R$. (B.) microplus, but without any correlation with attitudes towards controlling this tick. It was concluded that higher technological level and schooling level improved the producers' perceptions relating to the biology of the tick $R$. (B.) microplus, but did not achieve effectiveness with regard to using controls more rationally.
\end{abstract}

Keywords: Ixodidiosis, perception, cattle-rearing, Minas Gerais.

\section{Resumo}

Produtores de leite de Lavras, Passos e Divinópolis, MG, foram entrevistados com objetivo de avaliar sua percepção e atitude no controle do Rhipicephalus (Boophilus) microplus. A análise da correlaçáo multivariada entre as variáveis foi feita através de componentes principais (ACP). A percepção e atitude sobre o $R$. (B.) microplus foram semelhantes entre os produtores, sendo que a maioria deles náo tem o conhecimento básico sobre a biologia e o controle desse carrapato, aplicando os produtos carrapaticidas por meio de bomba costal, e sem critérios técnicos definidos. Alguns resultados obtidos foram: I. correlaçáo negativa entre escolaridade e frequência de aplicação de carrapaticidas bovinos; II. correlação positiva entre produçáo de leite, qualidade do equipamento para aplicaçáo carrapaticida e nível tecnológico da fazenda; III. propriedades com maior produção e tecnificação tenderam a manter o intervalo de aplicaçáo carrapaticida constante ao longo do ano. Após aplicação da ACP foi observada correlaçáo positiva entre escolaridade, nível tecnológico da fazenda e percepção sobre o $R$. (B.) microplus, porém, sem correlação com a atitude no controle deste carrapato. Concluiu-se que o nível tecnológico e a escolaridade melhoram a percepção dos produtores sobre a biologia do carrapato $R$. (B.) microplus, mas não alcança efetivos na utilizaçáo do controle de forma mais racional.

Palavras chave: Ixodidiose, percepção, bovinocultura, Minas Gerais.

\footnotetext{
*Corresponding author: Christiane Maria Barcellos Magalhães da Rocha Laboratório de Epidemiologia, Departamento de Medicina Veterinária, Universidade Federal de Lavras - UFLA, CEP 37200-000, Lavras, MG, Brasil e-mail: rochac@dmv.ufla.br

Financial support: Apoio FAPEMIG
} 


\section{Introduction}

It has been estimated that the losses due to ixodidiosis are of the order of billions of dollars per year in Brazil (GRISI et al., 2002). These losses can be expected to increase with the growth of dairy cattle herds, since the epidemiological situation of ixodidiosis and control over Rhipicephalus (Boophilus) microplus has changed very little over the years (ROCHA et al., 2006). Moreover, the tick populations that are resistant to acaricides have been increasing.

The state of Minas Gerais has the largest effective dairy cattle herd in Brazil, with 3.1 million head out of the 15 million head of dairy cattle in the country in 2007 (ANUALPEC, 2008).

The mild temperatures that occur in Minas Gerais throughout the year, with two well-defined seasons, make it possible for babesiosis to be endemic and give rise to the need to maintain enzootic stability, thus showing the importance of effective control over $R$. (B.) microplus. Based on this situation, it has been recommended that strategic tick control should be implemented (MARTINS et al., 2006). However, milk producers continue to undertake tick control without using any technical criteria and with a high frequency of treatments (ROCHA, et al., 2006, 2011b; AMARAL et al., 2011). Moreover, they use subjective parameters for applying and using acaricides (LEITE; ROCHA, 1999). These actions favor establishment of resistance to chemical products (SANTOS JUNIOR et al., 2000; SANTOS et al., 2009) and bring risks to human and animal health.

Studies by Rocha et al. (2006, 2011a, b) surveyed the profile of perceptions and attitudes among milk producers in Passos and Divinópolis, Minas Gerais, and demonstrated that there was a lack of knowledge of tick biology and a lack of alternatives for achieving more rational control. Considering that the tick control practices are all considered to be "traditional", the present study had the objective of evaluating factors associated with improvement of these control practices against $R$. (B.) microplus among the milkproducing farm properties in three municipalities with a tradition of dairy production in Minas Gerais. In addition to data from Passos (ROCHA et al., 2006) and Divinópolis (ROCHA et al., 2011a, b), information from Lavras, Minas Gerais, was also added.

The differential of this study is its use of principal component analysis. The study suggests that a new methodological perspective for evaluating multivariate associations can be used for this topic of perceptions and attitudes. Thus, the condition considered to present greatest vulnerability towards development of tick resistance to chemical products was the high frequency of applications, which brings greater selection pressure. Moreover, this study sought to construct quality indicators for perceptions, attitudes and technological levels, in order to study their associations. There is always a need to seek new methods for ever-greater elucidation of these social elements of parasitosis control.

\section{Materials and Methods}

\section{Data gathering}

Semi-systematized interviews were carried out among milk producers in Lavras, Passos and Divinópolis, state of Minas Gerais, regarding factors that characterized the technological level of production that they practiced and their attitude towards controlling the tick $R$. (B.) microplus, as well as their perceptions regarding the biology of this ixodid. The definitions for perceptions and attitudes were taken to be as follows: (I) perception - what the producer understands about tick biology or control, constructed through formal knowledge and practical experience; and (II) attitude - practical actions taken to control ticks.

The data used in this study were gathered from randomly chosen farm properties that had participated in previous studies. This made it possible to compare different production levels and provide a sufficient number of farms $(\mathrm{n}=193)$ for combined analyses on the 28 variables surveyed regarding: 1) characteristics of the properties and producers interviewed; 2 ) producers' perceptions regarding $R$. (B.) microplus; and 3) producers' attitudes regarding tick control. Associations among these variables were investigated.

The first study was carried out in Divinópolis, Minas Gerais by Rocha (1996) with participation from 105 producers. The second was carried out in Lavras, Minas Gerais $(n=63)$ and Passos, Minas Gerais ( $\mathrm{n}=25)$ (ROCHA et al., 2006). In Divinópolis, a list from the Municipal Department of Agriculture, dating from 1994, was used to randomly choose the interviewees to obtain a representative sample of the producers in the municipality. Divinópolis is represented by small family producers, and $96 \%$ of them were producing up to $200 \mathrm{~L}$ of milk per day.

However, to enable comparisons between different producer profiles, the producers in Lavras were chosen randomly according to stratified daily milk production groups, from the list of the agricultural cooperative. The groups were: 1) low production, up to $150 \mathrm{~L} /$ day $(\mathrm{n}=14) ; 2)$ medium production, 151 to $650 \mathrm{~L} /$ day $(\mathrm{n}=23)$; and 3) high production, more than $650 \mathrm{~L} / \mathrm{day}(\mathrm{n}=26)$. These data were gathered in 1999 and 2000.

In Passos $(n=25)$, only producers from the high production stratum of the municipality's agricultural cooperative (CASMIL) were selected randomly, and this was done in 2002.

To gather information, interviews were carried out using questionnaires that had previously been constructed and tested through the questionnaire validated by Rocha et al. (2006), which can be found as an annex in Rocha (1996). To analyze the information from the interviews, a database was constructed in the EpiData software, which was analyzed in the EpiInfo 6.04 and SPSS 12.0 software.

In this study, the questionnaires were constructed, the interview processes were conducted and the subsequent descriptive analyses of the data and description of the results were carried out in accordance with social research methodology (MINAYO, 1993; GIL, 1991), using questionnaires validated by Rocha et al. (2006, 2011a, b) and Amaral et al. (2011). 


\section{Statistical analysis}

The steps undertaken to assemble the database were: determination of the variables of interest; coding of the variables; and common categorization of the quantitative answers. The nominal qualitative variables were transformed in dichotomous variables (zero or one) by means of "content analysis" (MINAYO, 1993). Quality measurements equal to one corresponded to the categories that represented greater technification of production, better attitudes regarding the tick control and better perception of the biology or damage caused by $R$. (B.) microplus.

Some variables suffered losses due to lack of responses or responses that did not fit into the dichotomous categories. The ordinal quantitative and qualitative variables were maintained for the multidimensional analyses. The variables surveyed and used in this study can be seen, laid out in order, in Tables 1 to 4 .

To test associations between all the variables surveyed together, multidimensional principal component analysis was carried out. Initially, all the variables expressed in the study were used, and then those that showed smaller contributions in the first three axes were removed, taking into consideration the percentage variance explained by the axis (inertia of the system). During the first selection, the intention was to preserve at least four variables from each analysis category (1. technological level; 2 . perception of tick biology and damage; and 3. attitude towards tick control), which could be discarded or not over the course of the study. On a later occasion, selection was done to preserve the variables regarding tick control that were of greater importance for the study, such as the frequency of spraying/dipping, thus seeking to improve the accumulated percentage inertia for the third axis. The variables of frequency of acaricide spraying/dipping, production and number of vaccines used were quantitative. The schooling level and the animals' breed were ordinal categories and all the others were dichotomous.

Indicators of "Attitude", "Perception" and "Technological level" were constructed from the means of all the variables relating to these categories (Table 4). All the variables used in constructing the indicators were dichotomous, and thus, indicator values closer to one meant better perception, technological level or attitude, and values closer to zero indicated worse parameters. With these indicators and the variable of schooling level, principal component analysis was also carried out to test the multiple associations among variables.

\section{Results and Discussion}

The municipalities where the rural farm properties studied are located were shown to be associated with the production strata $(\mathrm{p}<0.05)$, because this was the strategy used to choose properties with a variety of technological levels, in order to support multivariate analysis. Thus, there is no way to separate the influences of the production stratum and municipality.

In Passos, although only producers from the high production stratum on the CASMIL list were chosen randomly, four were allocated to the medium stratum when interviewed, because they presented smaller production than what was registered on the list.

Great variation was noted among the parameters that characterized the producers and the properties studied and their

Table 1. Characterization of the farm properties used for milk production that were studied in the municipalities of Lavras, Passos and Divinópolis, state of Minas Gerais.

\begin{tabular}{|c|c|c|c|c|}
\hline Characteristic & P value ${ }^{1}$ & Va & Description & Frequency* \\
\hline \multirow[t]{2}{*}{ Area used for the dairy cattle** } & $\mathrm{P}>0.05$ & 0 & Up to 45 ha & 52.1 \\
\hline & & 1 & More than 45 ha & 47.9 \\
\hline \multirow[t]{2}{*}{ Mean daily total production of the property ${ }^{* *}$} & $\mathrm{P}>0.05$ & 0 & Up to $150 \mathrm{~L}$ & 50.8 \\
\hline & & 1 & More than $150 \mathrm{~L}$ & 49.2 \\
\hline \multirow[t]{2}{*}{ Mean production per cow per day** } & $\mathrm{P}>0.05$ & 0 & Up to $10 \mathrm{~L}$ & 60.3 \\
\hline & & 1 & More than $10 \mathrm{~L}$ & 39.4 \\
\hline \multirow[t]{2}{*}{ Number of vaccines applied to the cattle** } & $\mathrm{P}<0.05$ & 0 & Up to 3 & 69.9 \\
\hline & & 1 & More than 3 & 30.1 \\
\hline \multirow[t]{2}{*}{ Type of reproduction used } & $\mathrm{P}<0.05$ & 0 & Natural mounting & 58.5 \\
\hline & & 1 & Artificial insemination & 41.5 \\
\hline \multirow[t]{2}{*}{ Type of milking used } & $\mathrm{P}<0.05$ & 0 & Manual & 59.6 \\
\hline & & 1 & Mechanical & 40.4 \\
\hline \multirow[t]{4}{*}{ Cattle breed } & $\mathrm{P}<0.05$ & 1 & Zebu & 4.7 \\
\hline & & 2 & Crossbred (Holstein-Friesian Zebu) & 82.6 \\
\hline & & 3 & Holstein-Friesian & 12.6 \\
\hline & & - & Jersey or not known & 1.0 \\
\hline \multirow[t]{2}{*}{ Income source that the property represents to its owner } & $\mathrm{P}>0.05$ & 0 & Secondary or pastime & 29.1 \\
\hline & & 1 & Only or main & 70.9 \\
\hline \multirow[t]{3}{*}{ Owner's schooling level } & $\mathrm{P}<0.05$ & 1 & Up to end of elementary school & 54.5 \\
\hline & & 2 & High school & 20.9 \\
\hline & & 3 & University-level & 24.6 \\
\hline
\end{tabular}

$\mathrm{Va}=$ Value attributed to the characteristic described in the analysis $(0=$ lower, worse or less technified; $1=$ greater, better or more technified $) ;{ }^{*}$ frequency of valid answers as a percentage; ${ }^{* *}$ the cutoff point was determined by the median found; ${ }^{1}$ chi-square test. 
technological levels, thus demonstrating that there were different forms of milk production in the sample. This made it possible to test whether these factors demonstrated any relationship to the producers' perceptions and/or attitudes regarding control over $R$. (B.) microplus. The sample was composed of farm properties with total areas for dairy cattle of between 2 and 580 ha (71.4 \pm 81.9$)$; mean total production/day of between 6 and 2,800 L of milk $(454.6 \pm 627.0)$; and production per cow from 2 to $29 \mathrm{~L}$ of milk/ day $(10.2 \pm 5.5)$. As a sanitary level indicator, it was observed that some properties used only one type of vaccine, while others used up to six different types of vaccines $(3 \pm 1)$. All these parameters presented differences between the production strata $(\mathrm{p}<0.05)$.

Control over $R$. (B.) microplus on the farm properties studied was done without using any technical criteria. It was based mainly (75.6\%) on subjective observation of the infestation level that the owner considered acceptable, which could vary greatly, as observed by Leite and Rocha (1999). On most properties, only backpack sprayers were used as the equipment for acaricide treatment (Table 2). This equipment is considered to present low efficiency among the methods for acaricide application, especially because of the requirement to wet all parts of the animals' bodies. This implies using a large volume of acaricide in the application, and the spraying operator needs to make a great effort in this procedure, with high exposure to the chemical product (JONSSON; MATSCHOSS, 1998).

It was also observed that $72 \%$ of the producers used acaricide product volumes of less than $3.5 \mathrm{~L} /$ animal, which is considered to be the recommended quantity per animal (Table 2). Jonsson and Matschoss (1998), in Queensland, reported that 60\% of the milk producers interviewed used backpack spraying and, among these, $87 \%$ applied less than ten liters per animal.
The most concerning matter regarding control over $R$. (B.) microplus on the farm properties was the high frequency of spraying applied annually (Table 2 ), which favors establishment of genetic resistance of the ticks through selection (KUNZ; KEMP, 1994). The number of acaricide applications per year ranged from two to 60 applications $(17 \pm 9)$, without differences between the production strata $(\mathrm{p}>0.05)$.

Furthermore, on almost half the farm properties, differentiated spraying intervals according to the season were not used, which meant that there was no period without acaricide use. This management could favor maintenance of sensitive tick populations in the pastures and among the animals. Excess application not only increases the selection pressure towards resistant ticks, but also increases the amount of residue in the milk produced, thus signifying a public health risk.

A large proportion of the interviewees said that they used up to two commercial acaricide products in the treatments, but for $52.6 \%$, the reasons for changing the products did not follow any technical criteria. Some of the interviewees reported that they used the products that were available on the local market, according to the price, or the ones that were most recently launched on the market. The rotation that was established and products used varied according to the number of acaricide purchases made by the owners (Table 2).

Analysis on the perception variables showed that the owners had low levels of information regarding basic knowledge of tick biology and ecology and their importance as vectors for pathogens (Table 3). This was also observed by Rocha et al. (2006).

From the indicators that demonstrated together all the variables surveyed in relation to the factors that defined them, the previous information was confirmed. The great variation of technological level among the farm properties and the low mean values for "Attitude" showed that tick control tended to be done outside of the technical standards and not in a recommendable manner. An even smaller index was found to characterize "Perception", which

Table 2. Profile of producers' attitudes regarding tick control on the farm properties used for milk production that were studied in the municipalities of Lavras, Passos and Divinópolis, state of Minas Gerais.

\begin{tabular}{|c|c|c|c|c|}
\hline Characteristic & P value ${ }^{1}$ & Va & Description & Frequency* $^{*}$ \\
\hline \multirow[t]{2}{*}{ When to apply acaricide to the cattle } & $\mathrm{P}>0.05$ & 0 & Subjective observation & 75.6 \\
\hline & & 1 & Following a strategy & 24.4 \\
\hline \multirow[t]{2}{*}{ Number of products used } & $\mathrm{P}<0.05^{2}$ & 0 & More than two & 28.5 \\
\hline & & 1 & Up to two & 71.5 \\
\hline \multirow[t]{2}{*}{ Volume of liquid } & $\mathrm{P}<0.05^{2}$ & 0 & Up to $3.5 \mathrm{~L}$ per cow & 72.0 \\
\hline & & 1 & Other & 28.0 \\
\hline \multirow[t]{2}{*}{ Reason for changing products } & $\mathrm{P}>0.05$ & 0 & Others (e.g. cheaper, new, etc.) & 52.6 \\
\hline & & 1 & Resistance or more than 2 years of use & 47.4 \\
\hline \multirow[t]{2}{*}{ Spraying/dipping interval differentiated according to season } & $\mathrm{P}>0.05$ & 0 & Not done & 46.5 \\
\hline & & 1 & Done & 53.5 \\
\hline \multirow[t]{2}{*}{ Product concentration } & $\mathrm{P}<0.05^{2}$ & 0 & More or less concentrated & 43.0 \\
\hline & & 1 & Following recommendations & 57.0 \\
\hline \multirow[t]{2}{*}{ Equipment used } & $\mathrm{P}<0.05^{2}$ & 0 & Only backpack sprayer & 68.2 \\
\hline & & 1 & Other & 31.8 \\
\hline \multirow[t]{2}{*}{ Dichotomous annual frequency of spraying/dipping } & $\mathrm{P}<0.05^{2}$ & 0 & More than 11 & 80.2 \\
\hline & & 1 & Up to 10 & 19.8 \\
\hline
\end{tabular}

$\mathrm{Va}=$ Value attributed to the characteristic described in the analysis $(0=$ lower, worse or less technified; $1=$ greater, better or more technified $) ;$ frequency of valid answers as a percentage; ${ }^{* *}$ the cutoff point was determined by the median found; ${ }^{1}$ chi-square test. ${ }^{2}$ Independent variables were also associated with municipalities. 
Table 3. Profile of producers' perceptions regarding the biology and importance of the tick Rhipicephalus (Boophilus) microplus on farm properties used for milk production in the municipalities of Lavras, Passos and Divinópolis, state of Minas Gerais.

\begin{tabular}{|c|c|c|c|c|}
\hline Characteristics & P value ${ }^{1}$ & Va & Description & Frequency* \\
\hline \multirow[t]{2}{*}{ Knows favorable pasture } & $\mathrm{P}>0.05$ & 0 & No & 87.1 \\
\hline & & 1 & Yes & 12.9 \\
\hline \multirow[t]{2}{*}{ Knows unfavorable pasture } & $\mathrm{P}<0.05^{2}$ & 0 & No & 79.8 \\
\hline & & 1 & Yes & 20.2 \\
\hline \multirow[t]{2}{*}{ Knows number of eggs laid per oviposition } & $\mathrm{P}>0.05$ & 0 & Others & 78.2 \\
\hline & & 1 & Between 2,000 and 8,000 eggs & 21.8 \\
\hline \multirow[t]{2}{*}{ Knows parasite lifetime } & $\mathrm{P}<0.05^{2}$ & 0 & Others & 56.3 \\
\hline & & 1 & Between 15 and 30 days & 43.8 \\
\hline \multirow{2}{*}{$\begin{array}{l}\text { Knows time of the year with greatest incidence } \\
\text { of } R \text {. (B.) microplus }\end{array}$} & $\mathrm{P}<0.05^{2}$ & 0 & Others & 50.8 \\
\hline & & 1 & Summer, wet season or months between September and March & 49.2 \\
\hline \multirow[t]{2}{*}{ Knows length of survival in the pasture } & $\mathrm{P}>0.05$ & 0 & Others & 88.1 \\
\hline & & 1 & Between 80 and 180 days & 11.9 \\
\hline \multirow[t]{2}{*}{ Knows losses due to ticks } & $\mathrm{P}<0.05^{2}$ & 0 & Just loss of milk and weight & 64.2 \\
\hline & & 1 & Knows that it causes disease & 35.8 \\
\hline \multirow[t]{2}{*}{ Knows the causes of losses } & $\mathrm{P}>0.05$ & 0 & Others & 79.3 \\
\hline & & 1 & Knows that it transmits disease & 20.7 \\
\hline \multirow[t]{2}{*}{ Knows other forms of control } & $\mathrm{P}<0.05^{2}$ & 0 & Others & 78.8 \\
\hline & & 1 & No, just chemical acaricide & 21.2 \\
\hline
\end{tabular}

$\mathrm{Va}=$ Value attributed to the characteristic described in the analysis $\left(0=\right.$ lower, worse or less technified); ${ }^{*}$ frequency of valid answers as a percentage; ${ }^{* *}$ the cutoff point was determined by the median found; ${ }^{1}$ chi-square test; ${ }^{2}$ Independent variables were also associated with municipalities.

showed that there was a high level of misinformation among the producers interviewed (Table 4).

According to Elder et al. (1980), 20\% of the milk producers in Queensland, Australia, used strategic tick control, while Jonsson and Matschoss (1998) found that $40 \%$ used this control strategy. Regarding the other $60 \%$, when they were asked why they were not using strategic control, half answered that there was no need, 9\% did not believe in the benefits and the other answers related to cost and labor, among other matters. The producers that most used strategic control were those that considered ticks to be a serious health problem for the cattle. This shows that, as well as information, there are other obstacles that have to be overcome in order to achieve effective control over $R$. (B.) microplus in the herds. In the present study, five producers $(2.6 \%)$ used strategic control: one was in the municipality of Passos and the others were in the municipality of Lavras, where Oliveira (1993) carried out a study on the efficiency of this control method.

In Figure 1, the perception variables were excluded from the study, because they had little importance for explaining the inertia after the preliminary analysis. The type of milking and the mean milk production per day were the most important variables for characterizing the technological level and were shown to be highly associated, as was expected. In other words, farm properties with high milk production tend to have a mechanical milking system, which was classified as "high technological level". The acaricide application equipment accompanied the technological level with a high association, showing that properties with high technological level tend to use other equipment to apply acaricide products, besides backpack sprayers. Among such equipment, other forms of application were also considered, like the pour-on method, which has grown in use because it is easy to apply. However, these variables showed a negative correlation with the seasonal spraying/dipping interval, i.e. the farms with greater production/day, mechanical milking and better equipment for acaricide application tended to maintain the frequency of spraying/dipping throughout the year.

The frequency of annual acaricide application was inversely correlated with the interviewee's schooling level. In other words, the owners with lower schooling level tended to apply spraying at shorter intervals, thereby speeding up the selection for resistance to acaricides. Santos et al. (2009) demonstrated that these two factors are considered to present a risk of selection for tick resistance.

Higher annual frequency of spraying/dipping was strongly associated with use of spraying spaced throughout the year and use of backpack sprayers alone. The technology variables were positively correlated with the schooling level.

Figure 2 shows that the technological level indicator, the dichotomous schooling level (up to the end of elementary school and from high school level onwards) and the "Perception Indicator" were positively correlated, especially the two first parameters, which presented the same direction in relation to the third axis. 
Table 4. Indicators of technological level, perception of Rhipicephalus (Boophilus) microplus and attitude towards control on the farm properties used for milk production that were studied in the municipalities of Lavras, Passos and Divinópolis, state of Minas Gerais.

\begin{tabular}{|c|c|c|c|c|}
\hline Indicators & Composition* & $\begin{array}{l}\text { Differences per pro- } \\
\text { duction stratum }^{1}\end{array}$ & Mean \pm SD & Min-Max ${ }^{* *}$ \\
\hline $\begin{array}{l}\text { Technological } \\
\text { level }\end{array}$ & $\begin{array}{l}\text { (Production per cow/day + Number of vaccines + Reproduction + Milking } \\
+ \text { Breed }^{2}+\text { Mean production per farm/day) } / 6 \text {. }\end{array}$ & $* * *$ & $0.36 \pm 0.33$ & $00-1.00$ \\
\hline Perception & $\begin{array}{l}\text { (Knows the number of eggs/laying }+ \text { Knows parasite lifetime }+ \text { Knows time } \\
\text { of the year with greatest incidence of } R .(B .) \text { microplus }+ \text { Knows length of } \\
\text { survival in the pasture }+ \text { Knows that ticks cause diseases }+ \text { Knows that ticks } \\
\text { transmit pathogens }+ \text { Knows other forms of tick control) } / 7 \text {. }\end{array}$ & $\mathrm{P}<0.05$ & $0.29 \pm 0.14$ & $00-0.86$ \\
\hline Attitude & $\begin{array}{l}\text { When to apply acaricide to the cattle }+ \text { Number of products used }+ \text { Spray- } \\
\text { ing/dipping frequency }+ \text { Mean volume of liquid used/animal }+ \text { Reasons } \\
\text { for changing acaricide }+ \text { Spraying/dipping interval differentiated between } \\
\text { seasons + Concentration of the acaricide liquid used }+ \text { Equipment used)/8 }\end{array}$ & $\mathrm{P}>0.05$ & $0.41 \pm 0.16$ & $00-0.88$ \\
\hline
\end{tabular}

*All the variables used were dichotomous and their attributes can be seen in Tables 1 to 3 , except the following variable: ${ }^{2}$ Breed (one $=$ Holstein and zero $=$ others); **Zero: minimum value, corresponding to the smallest degrees of technological level, perception and attitude; One: maximum value, corresponding to the greatest levels; ${ }^{* * *}$ Production stratum was not tested because it was a component of the indicator; ${ }^{1}$ Kruskal-Wallis test (when there was no homoscedasticity through the Duncan test) or ANOVA.

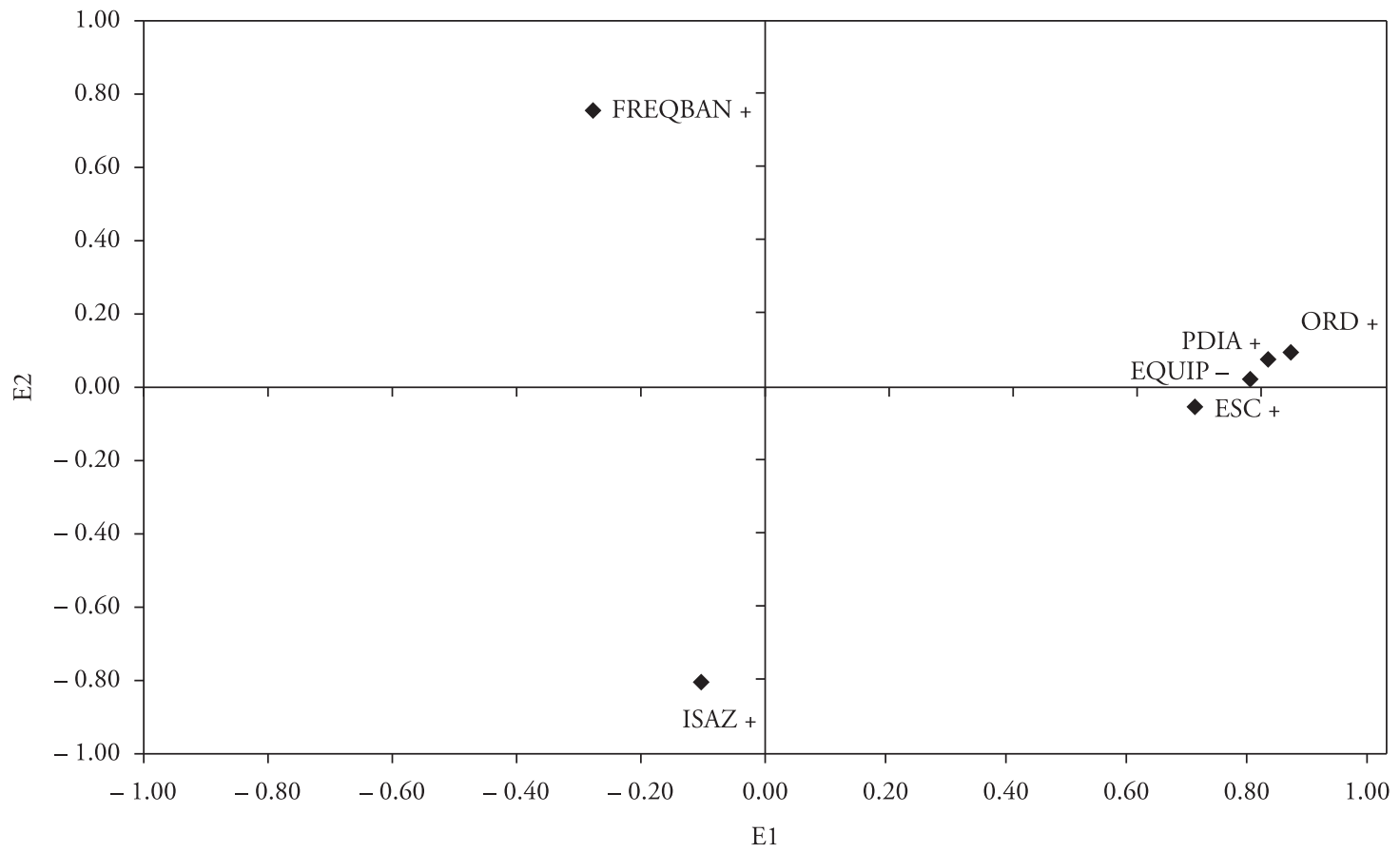

Figure 1. Principal components of the variables of technological level, perception of Rhipicephalus (Boophilus) microplus and attitude of the milk producers towards tick control in the municipalities of Lavras, Passos and Divinópolis, Minas Gerais. + positive values on the $3^{\text {rd }}$ axis; - negative values on the $3^{\text {rd }}$ axis; accumulated inertia up to the $3^{\text {rd }}$ axis: $76.31 \%$. ISAZ $=$ Spraying/dipping interval differentiated according to season; EQUIP = Equipment used for application of acaricides; FREQBAN = annual frequency of spraying/dipping; PDIA = mean milk production/day; ORD = type of milking used; and ESC = owners' schooling level.

This shows that there was a tendency to find higher schooling levels on farm properties with greater production and productivity and with better technical resources. There was also a tendency for owners with higher schooling and technological levels to present better perceptions regarding ticks, although this correlation was less intense, as represented by the observed distance from the third axis. Nevertheless, surprisingly, the attitude regarding tick control was not correlated with any of these factors. This demonstrated the great difficulty in modifying the reality of $R$. (B.) microplus control on the farm properties in question.

Multiple-correlation analysis is the differential of this study, which provides combined analysis of the data described by Rocha et al. (2006, 2011b) and also puts forward a proposal for similar studies on perceptions and attitudes. 


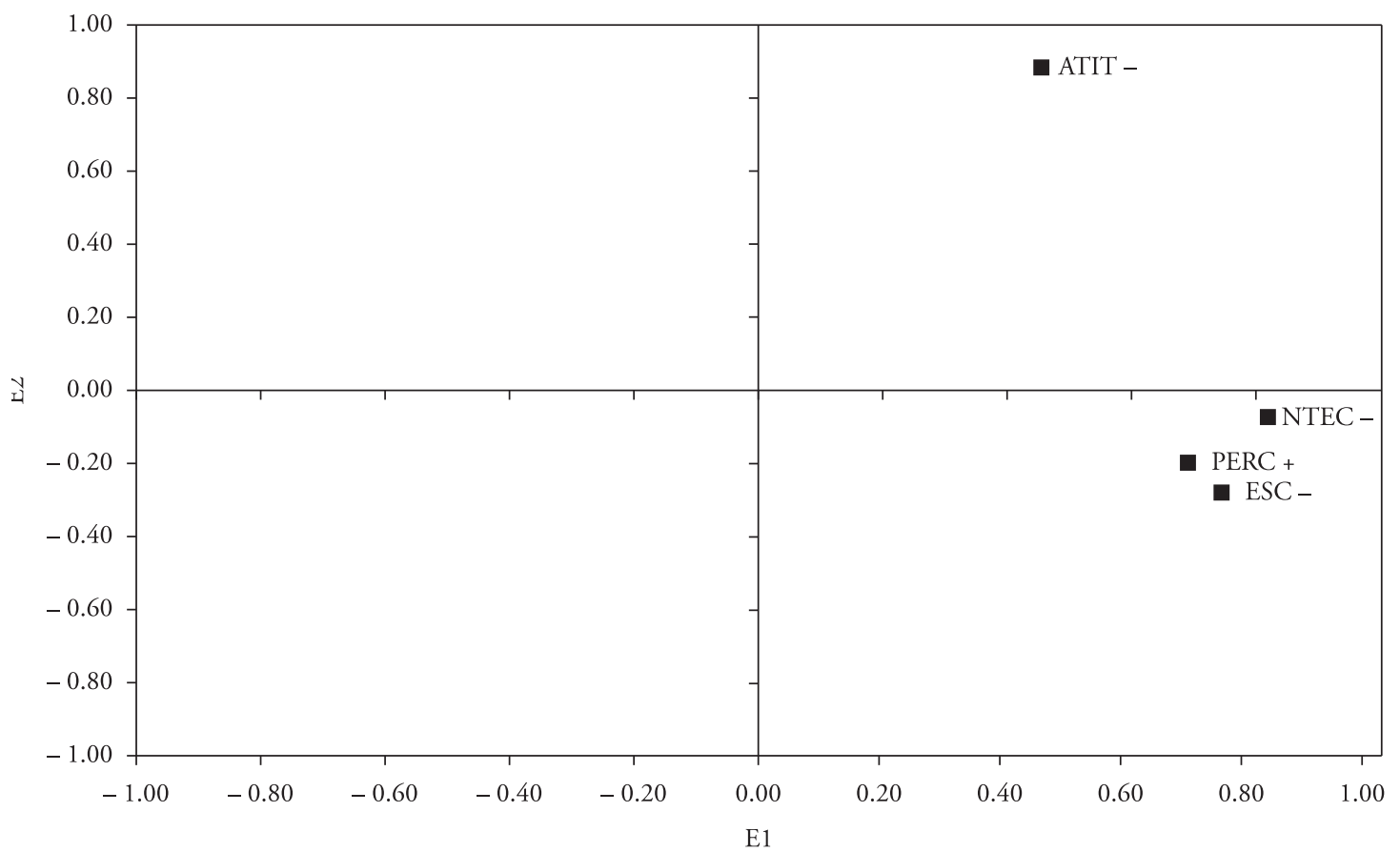

Figure 2. Principal components of the indicators of technological level, schooling level, perception of Rhipicephalus (Boophilus) microplus and attitude of the milk producers towards tick control in the municipalities of Lavras, Passos and Divinópolis, Minas Gerais. + positive values on the $3^{\text {rd }}$ axis; - negative values on the $3^{\text {rd }}$ axis; accumulated inertia up to the $3^{\text {rd }}$ axis: $88.22 \%$. ATIT = attitude regarding control over $R$. (B.) microplus; PERCEP = perception of the biology of $R$. (B.) microplus; ESC = owners' schooling level; and NTEC = technological level of the farm property.

\section{Conclusions}

The producers that presented a better technological level used better equipment to apply the acaricide and tended to maintain greater intervals between applications throughout the year.

The perceptions of the biology and importance of $R$. (B.) microplus among the producers interviewed were considered low, and their attitudes were inadequate for tick control. Continuing education programs need to be encouraged by government bodies and/or cooperatives and private initiative, in order to transmit the necessary information to producers, for rational tick control.

Schooling level and technological level presented an association with perceptions regarding ticks, but without influencing the attitudes relating to tick control.

\section{References}

Amaral MAZ, Rocha CMBM, Faccini JL, Furlong J, Monteiro CMO, Prata MCA. Strategic Control of Cattle Ticks: milk producers' perceptions. Rev Bras Parasitol Vet 2011; 20(2): 148-154. http://dx.doi. org/10.1590/S1984-29612011000200010

Anuário da Pecuária Brasileira - ANUALPEC. [online]. São Paulo: Instituto FNP; 2008. Available from: http://www.gaz.com.br/editora/ anuarios/3144.html

Elder JK, Emmerson FR, Kearnan JF, Waters KS, Dunwell GH, Morris RS, et al. A survey concerning cattle tick control in Queensland: 3. Quimical control. Aust Vet J 1980; 56(5): 212-218. http://dx.doi. org/10.1111/j.1751-0813.1980.tb15974.x
Gil, A. C. Métodos e técnicas de pesquisa social. São Paulo: Editora Atlas S.A.; 1991.

Grisi L, Massard CL, Moya-Borja GE, Pereira JB. Impacto econômico das principais ectoparasitoses em bovinos no Brasil. A Hora Veterinária 2002; 21(125): 8-10.

Jonsson NN, Matschoss AL. Attitudes and practices of Queensland dairy farmers to the control of the cattle tick, Boophilus microplus. Aust Vet J1998; 76(11): 746-751. http://dx.doi.org/10.1111/j.1751-0813.1998. tb12306.x

Kunz SE, Kemp DH. Insecticides and acaricides: resistance and environmental impact. Rev Sci Tech 1994; 13(4): 1249-1286.

Leite RC, Rocha CMBM. Contagens de carrapatos em bovinos no momento do banho carrapaticida em rebanhos leiteiros do Município de Divinópolis/MG. Arq Bras Med Vet Zootec 1999; 51(1): 41-42.

Martins JRS, Furlong J, Leite RC. Controle de carrapatos. In: BarrosBattesti DM, Arzua M, Bechara GH. Carrapatos de importância médicoveterinária da região neotropical: Um guia ilustrado para identificação de espécies. São Paulo: Vox, ICTTD-3, Butantã; 2006. p. 53-113.

Minayo MCS. $O$ desafio do conhecimento: Pesquisa qualitativa em saúde. 2 ed. São Paulo: HUCITEC, Rio de Janeiro: ABRASCO; 1993.

Oliveira PR. Controle estratégico do Boophilus microplus (Canestrini,1887) em bovinos de propriedades rurais dos municípios de Lavras e Entre Rios de Minas, Minas Gerais [Dissertação]. Minas Gerais: Universidade Federal de Minas Gerais; 1993.

Rocha, CMBM. Caracterização da percepção dos produtores de leite do município de Divinópolis/MG sobre a importância do carrapato Boophilus 
microplus e fatores determinantes das formas de combate utilizadas [Dissertação]. Minas Gerais: Universidade Federal de Minas Gerais; 1996.

Rocha CMBM, Leite RC, Bruhn FRP, Guimarães AM, Furlong J. Perceptions about the biology of Rhipicephalus (Boophilus) microplus among milk producers in Divinópolis, Minas Gerais. Rev Bras Parasitol Vet 2011a; 20(4): 289-294. http://dx.doi.org/10.1590/S198429612011000400006

Rocha CMBM, Leite RC, Bruhn FRP, Guimarães AM, Furlong J. Perceptions of milk producers from Divinópolis, Minas Gerais, regarding Rhipicephalus (Boophilus) microplus control. Rev Bras Parasitol Vet 2011b; 20(4): 295-302. http://dx.doi.org/10.1590/S198429612011000400007
Rocha CMBM, Oliveira PR, Leite RC, Cardoso DL, Calic SB, Furlong J. Percepção dos produtores de leite do município de Passos, MG, sobre o carrapato Boophilus microplus (Acari: Ixodidae), 2001. Ciênc Rural 2006; 36(4): 1235-1242. http://dx.doi.org/10.1590/S010384782006000400029

Santos Junior JBC, Furlong J, Daemon E. Controle do carrapato Boophilus microplus (Acari: Ixodidae) em sistemas de produção de leite da microrregiáo fisiográfica Fluminense do Grande Rio - Rio de Janeiro. Ciênc Rural 2000; 30(2): 305-311.

Santos TRB, Farias NAR, Filho NAC, Pappen FG, Junior ISV. Abordagem sobre o controle do carrapato Rhipicephalus (Boophilus) microplus no Sul do Rio Grande do Sul. Pesq Vet Bras 2009; 29(1): 65-70. http://dx.doi.org/10.1590/S0100-736X2009000100010 